\title{
PERSEPSI MASYARAKAT TERHADAP PERKEMBANGAN PRODUK PERBANKAN DAN IKNB SYARIAH DI KOTA PEKANBARU
}

\author{
Fitriana Payabadar ${ }^{1} \&$ Husni Thamrin ${ }^{2}$ \\ ${ }^{1 \& 2}$ Program Studi Ekonomi Syariah, Pascasarjana Universitas Islam Negeri Suska Riau \\ Email : fitriana130395@gmail.com, husni2017husni@gmail.com
}

\begin{abstract}
ABSTRAK
Penelitian ini dilatar belakangi oleh fenomena pandangan masyarakat Kota Pekanbaru yang masih beranggapan bahwasannya ekonomi syariah masih sama dengan ekonomi konvensional. Hanya saja ekonomi syariah hanya menggunakan margin dan ekonomi konvensional menggunakan bunga. Penelitian ini bersifat deskriptif dan data yang digunakan ialah data primer dan sekunder. Pengumpulan data primer dilakukan melalui angket dan disebarkan kepada masyarakat kota pekanbaru, sedangkan data sekunder diperoleh dari buku, internet, dan media-media lainnya. Metode analisis yang digunakan adalah metode statistik deskriptif yaitu penyajian data dengan tabel, grafik, diagram lingkaran, dan persentase kemudian dideskriptifkan (dipaparkan). Populasi dalam penelitian ini sebanyak 1.091 .088 orang dan sampel sebanyak 100 orang. Dari 100 responden yang diteliti, 46,24\% menyatakan sangat setuju, 39,58\% menyatakan setuju, 12,25\% menyatakan netral, $1,75 \%$ menyatakan tidak setuju, dan $0,16 \%$ menyatakan sangat tidak setuju. Hasil penelitian di analisis menggunakan rentang analisis deskriptif yakni terletak pada $46 \%$ yakni cukup baik. Rentang nilai cukup baik yakni $41 \%$ - $60 \%$.
\end{abstract}

Kata Kunci: Persepsi, Ekonomi Syariah, Perbankan Syariah, IKNB Syariah.

\section{ABSTRACT}

This reseach was motivated by the phenomenon of community perception in Pekanbaru that assumed syaria economy is still same as conventional economy where Syaria economy used margin while conventional economy used interest. This was descriptive reseach and used primary and secondary data. In collectiong primary data, it used questionnaires and then distributed to people in Pekanbaru while secondary data was obtained from books, internet, and other media. Analysis method used statistic descriptive means presenting data in form of table, lines, pie charts and percentages then described. Total populations in this reseach were 1.091 .088 and samples were 100 respondents. From 100 respondents, 46.24 stated strongly agree, $39.58 \%$ stated agree, 12.25 stated netral, $1.75 \%$ stated disagree and $0.16 \%$ stated strongly disagree. The result of this reseach was analyzed by range analysis descriptive that placed at 46\% means enough. The range of enough placed at $41 \%-60 \%$.

Keywords: Perception, Syaria Economy, Islamic Banking and IKNB Syariah. 


\section{PENDAHULUAN}

Penduduk Indonesia mayoritas beragama Islam, sehingga sepantasnya Indonesia mengembangkan sistem perekonomian syariah agar menjadi pusat ekonomi syariah dunia. Secara global, berdasarkan data Global Islamic Economic Indikator 2017, Indonesia berada di posisi 10. Perkembangan ekonomi syariah terus dikebut pertumbuhannya. Saat ini Indonesia berada ditingkat ke 9 dunia dikategori total aset keuangan syariah, masih jauh ketinggalan dengan negara tetangga yakni Malaysia yang menempati posisi ke 3 .

Lembaga keuangan syariah bank maupun industri keuangan non bank di Indonesia di awasi oleh Otoritas jasa Keuangan (OJK). Industri Keuangan Non Bank berkembang di Indonesia secara umum merupakan industri yang menyelenggarakan kegiatan usahanya disektor jasa keuangan, selain sektor bank dan pasar modal.

Industri Keuangan Non Bank (IKNB) di Indonesia berkembang pesat pada dekade terakhir. Sejumlah perusahaan berlomba-lomba meningkatkan kinerja untuk memajukan perusahaan dan dapat dilihat dari periode Desember 2017. Perusahaan IKNB di Indonesia berjumlah 54 unit dan tersebar diseluruh Indonesia, khususnya di Provinsi Riau yang berpusat di Kota Pekanbaru. Perkembangan lembaga keuangan di kota Pekanbaru, juga menunjukkan perkembangan yang sangat pesat dengan berdirinya perusahaanperusahaan non bank seperti asuransi, lembaga pembiayaan, serta lembaga keuangan mikro yang tercatat oleh OJK. Dengan meningkatnya IKNB konvensional menuntut IKNB syariah untuk meningkatkan performanya sehingga bisa ikut bersaing dikalangan lembaga keuangan. Hal ini menunjukkan bahwa pangsa pasar syariah memiliki potensi lebih besar dan prospek keuangan syariah pada masa yang akan datang.

\section{TINJAUAN PUSTAKA}

\section{Pengertian Persepsi}

Dalam bahasa Inggris, persepsi adalah perception, yaitu cara pandang terhadap sesuatu atau mengutarakan pemahaman hasil olahan daya pikir, artinya persepsi berkaitan dengan faktorfaktor eksternal yang direspon melalui pancaindra, daya ingat dan daya jiwa. (Mursidin, 2010)

Persepsi adalah pengalaman tentang objek, peristiwa, atau hubunganhubungan yang diperoleh dengan menyimpulkan informasi dan menafsirkan pesan. Persepsi ialah memberikan makna stimulasi inderawi (sensor stimuli). (Rakhmat, 2012)

Persepsi pada hakikatnya adalah proses kognitif yang dialami oleh setiap orang didalam memahami informasi tentanglingkungannya, baik lewat penglihatan, pendengaran, penghayatan, perasaan dan penciuman. Kunci untuk memahami persepsi adalah terletak pada pengenalan bahwa persepsi itu merupakan suatu penafsiran yang unik terhadap situasi, bukannya suatu pencatatan yang benar terhadap situasi. (Toha 2008)

Persepsi lebih dari sekedar penerimaan pasif informasi. Persepsi adalah sebuah proses aktif. Perabaan misalnya, membutuhkan gerakan sesuatu yang kini kita sebut "scanning". Perabaan mencakup informasi tentang anda dan juga tentang apa yang sedang anda sentuh. Kita bisa mengatakan hal yang sama terhadap pendengaran. Kita seharusnya betul-betul menyebutnya mendengar. Suara itu sendiri tentu secara intrinsik bergerak ia terus menerus berubah. Jika tidak, kita akan berhenti mendengarnya. (Boeree, 2016)

Persepsi meliputi aktivitas menerima stimuli, mengorganisasi stimuli tersebut, dan menerjemahkan atau 
menafsirkan stimuli yang terorganisasi tersebut demikian rupa hingga ia dapat memengaruhi perilaku dan membentuk sikap. (Winardi, 2015)

\section{Faktor-faktor Mempengaruhi Persepsi}

Berbagai macam faktor-faktor berasal dari luar maupun dari dalam dapat mempengaruhi proses seleksi persepsi. (Toha 2012)

1) Faktor Internal

Adapun faktor internal diantaranya:

a. Pemahaman

Merupakan kemampuan seseorang untuk memahami sesuatu sehingga menimbulkan adanya persepsi adalah berdasarkan dari kekomplekan kejiwaan seperti yang diuraikan dimuka.

\section{b. Motivasi}

Pengertian motivasi dalam Kamus Besar Bahasa Indonesia (KBBI) adalah dorongan yang timbul pada diri seseorang secara sadar atau tidak sadar untuk melakukan suatu tindakan dengan tujuan tertentu.

c. Kepribadian

Merupakan perbedaan pendapat dalam menyelesaikan suatu masalah antar dua orang atau kelompok yang masing-masing bertahan terhadap pendapat mereka tersebut.

\section{2) Faktor eksternal}

Adapun faktor ekternal diantaranya:

a. Intensitas

Prinsip dari suatu perhatian dapat dinyatakan bahwa semakin besar intensitas stimulus dari luar, layaknya semakin besar pula hal-hal itu dapat dipahami.

\section{b. Ukuran}

Faktor ini menyatakan bahwa semakin besar ukuran sesuatu objek, maka semakin mudah untuk bisa diketahui atau dipahami.

c. Keberlawanan

Prinsip keberlawanan ini menyatakan bahwa stimulus luar yang penampilannya sangat berlawan dengan latar belakangnya atau sekelilingnya akan menarik banyak perhatian.

d. Pengulangan

Dalam prinsip ini dikemukakan bahwa stimulasi yang diulang dari luar akan memberikan perhatian yang lebih besar dibandingkan dengan hanya sekali dilihat.

e. Gerakan

Orang yang memberikan banyak perhatian terhadap objek yang bergerak dalam jangkauan pandangan dibandingkan objek diam.

\section{f. Kebaruan}

Prinsip ini menyatakan bahwa baik situasi eksternal yang baru maupun yang sudah dikenal dapat dipergunakan sebagai penarik perhatian.

\section{Pengertian Bank Syariah}

Secara Umum pengertian bank Islam (Islamic bank) adalah bank yang pengoperasiannya disesuaikan dengan prinsip syariat Islam. Saat ini banyak istilah yang diberikan untuk menyebut entitas bank Islam, selain istilah bank Islam itu sendiri, yaitu bank tanpa bunga (interest-free bank), bank tanpa riba (lariba bank), dan bank syariah (shari'a bank). (Usman, 2012)

Di Indonesia, regulasi mengenai bank syariah tertuang dalam UndangUndang No. 21 Tahun 2008 tentang perbankan syariah. Bank syariah adalah 
bank yang menjalankan kegiatan usahanya berdasarkan prinsip-prinsip syariah dan menurut jenisnya terdiri atas Bank Umum Syariah, Unit Usaha Syariah dan Bank Pembiayaan Rakyat Syariah (BPRS). (Soemitra, 2009)

Perkembangan perkembangan syariah ini tentunya juga harus didukung oleh sumber daya insani yang memadai, baik dari segi kualitas maupun kuantitasnya. Namun, realitas yang ada menunjukkan bahwa masih banyak sumber daya insani yang selama ini terlibat di institusi syariah tidak memiliki pengalaman akademis maupun praktis dalam Islamic banking. Tentunya kondisi ini cukup signifikan mempengaruhi produktivitas dan profesionalisme perbankan syariah itu sendiri. Inilah yang harus mendapatkan perhatian kita semua, yakni mencetak sumber daya insani yang mampu mengamalkan ekonomi syariah di semua ini karena sistem yang baik tidak mungkin dapat berjalan bila tidak didukung oleh sumber daya insani yang baik pula. (Karim, 2014)

\section{Industri Keuangan Non Bank (IKNB)}

IKNB Syariah merupakan aktivitas di industri asuransi, dana pensiun, lembaga pembiayaan, dan lembaga jasa keuangan lainnya, yang dalam pelaksanaannya tidak bertentangan dengan prinsip-prinsip syariah. Secara umum, kegiatannya memang tidak memiliki perbedaan dengan IKNB konvensional. Namun IKNB Syariah memiliki karakteristik khusus, dengan produk dan mekanisme transaksi yang berdasarkan Al-Qur'an dan hadist.

Fatwa Dewan Syariah Nasional Majelis Ulama Indonesia (DSN MUI) tentang Lembaga Keuangan Syariah (LKS) ialah "Pembiayaan Mudharabah (Qiradh), Pembiayaan Musyarakah, Pembiayaan Ijarah, Wakalah, Akad Mudharabah Musytarakah, dan Akad Kafalah”.

$$
\text { Otoritas Jasa Keuangan (OJK) }
$$
merupakan lembaga pengatur dan pengawas di keuangan syariah yang memiliki fungsi dan kewenangan untuk melakukan integrasi arah kebijakan, strategi, dan tahapan pengembangan di industri keuangan syariah, termasuk di IKNB Syariah. Instrumen regulasi yang dikeluarkan oleh OJK sesuai dengan prinsip syariah, dengan melibatkan DSN MUI.

\section{Definisi Masyarakat}

Masyarakat adalah kesatuan sosial yang mempunyai ikatan kasih sayang erat. Individu dalam masyarakat merupakan kesatuan yang saling bergaul, saling berinteraksi sehingga membentuk kehidupan yang mempunyai jiwa. Jiwa masyarakat ini merupakan potensi yang berasal dari unsur-unsur masyarakat, meliputi pranata, status dan peran sosial. (Ismawati, 2012)

Masyarakat merupakan sistem adaptif, karena masyarakat merupakan wadah untuk memenuhi berbagai kepentingan dan kebutuhan untuk bertahan. Kebutuhan yang diperlukan antara lain : adanya populasi, informasi, energi, materi, sistem komunikasi, sistem produksi, sistem distribusi, sistem organisasi sosial, sistem perlindungan sosial, perlindungan warga masyarakat terhadap ancaman-ancaman yang tertuju pada jiwa dan harta bendanya. (Ismawati, 2012)

\section{Ekonomi Islam}

Iqtishad (ekonomi) didefinisikan dengan pengetahuan tentang aturan yang berkaitan dengan pengetahuan tentang aturan yang berkaitan dengan produksi kekayaan, mendistribusikan dan mengkonsumsinya. Ekonomi pada umumnya didefinisikan sebagai kajian tentang perilaku manusia dalam hubungannya dengan pemanfaatan sumbersumber produksi yang langka untuk diproduksi dan dikonsumsi. (Rozalinda, 2014) 
Ekonomi Islam dibangun atas dasar agama Islam, karenanya ia merupakan bagian tak terpisahkan (integral) dari agama Islam. Sebagai derivasi dari agama Islam, ekonomi Islam akan mengikuti agama Islam dalam berbagai aspeknya. Islam adalah sistem kehidupan (way of life), dimana Islam telah menyediakan berbagai perangkat aturan lengkap bagi kehidupan manusia, termasuk dalam bidang ekonomi. (Pusat Kajian dan Pengembangan Ekonomi Islam (P3EI) UIIY, 2015)

\section{METODE PENELITIAN}

Jenis penelitian yang digunakan dalam penelitian ini adalah jenis penelitian lapangan (field research) dengan metode deskriptif. Jenis penelitian deskriptif adalah jenis penelitian yang disusun dalam rangka memberikan gambaran secara sistematis tentang informasi ilmiah yang berasal dari subjek atau objek penelitian. (Sanusi, 2011)

Data Primer adalah data yang diperoleh peneliti dari sumber asli. Dalam hal ini, maka proses pengumpulan datanya perlu dilakukan dengan memperhatikan siapa sumber utama yang akan dijadikan objek penelitian. Yaitu berupa angket/kuesioner yang diisi oleh responden (Muhammad, 2008).

Data Sekunder adalah sumber data yang diperoleh secara tidak langsung dan hanya melalui media perentara. Data ini diperoleh dari literatur-literatur yang berkaitan dengan judul yang penulis buat. Yaitu berupa jurnal, buku-buku yang terkait dan penelitian yang relevan dengan judul peneliti. (Muhammad, 2008)

Data yang diolah dari angket dalam bentuk tabel, kemudian diinterpretasikan berdasarkan skor untuk mengetahui tingkat pengetahuan masyarakat Kota Pekanbaru dengan interprestasi skor sebagai berikut : (Riduwan, 2014)

$$
\begin{array}{ll}
81 \%-100 \% & =\text { Sangat Baik } \\
61 \%-80 \% & =\text { Baik } \\
41 \%-60 \% & =\text { Cukup Baik } \\
21 \%-40 \% & =\text { Kurang Baik } \\
0 \%-20 \% & =\text { Kurang Baik Sekali }
\end{array}
$$

\section{HASIL DAN PEMBAHASAN}

Jenis survei yang digunakan dalam survei ini adalah jenis survei lapangan (field survey) dengan metode deskriptif. Jenis penelitian deskriptif adalah jenis penelitian yang disusun sedemikian rupa untuk memberikan gambaran yang sistematis tentang informasi ilmiah yang berasal dari subjek atau objek penelitian.

Identitas responden dalam kegiatan penelitian sangat penting untuk mengetahui jenis kelamin, kecamatan, usia, pendidikan, dan pekerjaan yang dijadikan sampel. Identitas responden nantinya akan menjadi pedoman dalam pengambilan kesimpulan hasil penelitian. Berdasarkan apa yang di angkat dapat diidentifikasi karakteristik yaitu jenis kelamin, usia, kecamatan, pendidikan, pekerjaan, penghasilan dari responden. Karakteristik identitas responden masyarakat Pekanbaru.

\section{Persepsi Masyarakat Terhadap Perkembangan Produk Perbankan dan IKNB Syariah di Kota Pekanbaru}

Hasil penelitian mengenai PersepsiMasyarakat Terhadap Ekonomi Syariah dan Potensinya Terhadap Perkembangan Ekonomi Syariah Di Pekanbaru, yang mencakup tentang indikator internal dan eksternal. Adapun tanggapan masyarakat tentang persepsi masyarakat terhadap ekonomi syariah dan potensinya terhadap perkembangan ekonomi syariah di pekanbaru adalah sebgai berikut :

\section{a. Faktor Internal}

Adapun faktor-faktor dalam diri sendiri seseorang yang mempengaruhi 
proses persepsi antara lain: Pemahaman, Motivasi,

dan

Kepribadian.

Tabel 1. Faktor Internal

\begin{tabular}{|c|c|c|c|c|c|c|c|}
\hline \multirow[b]{2}{*}{ No } & \multirow[b]{2}{*}{$\begin{array}{c}\text { Butir } \\
\text { Pernyataan }\end{array}$} & \multicolumn{5}{|c|}{ Skala Pengukuran } & \multirow[b]{2}{*}{ Jumlah } \\
\hline & & $\begin{array}{l}\text { Sangat } \\
\text { Setuju }\end{array}$ & Setuju & Netral & $\begin{array}{c}\text { Tidak } \\
\text { Setuju }\end{array}$ & $\begin{array}{c}\text { Sangat } \\
\text { Tidak } \\
\text { Setuju }\end{array}$ & \\
\hline 1 & Pernyataan 1 & 75 & 20 & 5 & 0 & 0 & 100 \\
\hline 2 & Pernyataan 2 & 56 & 31 & 11 & 2 & 0 & 100 \\
\hline 3 & Pernyataan 3 & 36 & 48 & 14 & 2 & 0 & 100 \\
\hline 4 & Pernyataan 4 & 45 & 40 & 8 & 7 & 0 & 100 \\
\hline 5 & Pernyataan 5 & 33 & 45 & 17 & 4 & 1 & 100 \\
\hline 6 & Pernyataan 6 & 42 & 44 & 10 & 3 & 1 & 100 \\
\hline & Jumlah & 287 & 228 & 65 & 18 & 2 & 600 \\
\hline & Persentase & 47,83 & 38 & 10,83 & 3 & 0,33 & 100 \\
\hline
\end{tabular}

Sumber : Data Olahan (2018)

Berdasarkan tabel di atas, dapat setuju dengan persentase penelitian dilihat bahwa sebagian responden $47,83 \%$. memiliki faktor internal dalam persepsi masyarakat, tanggapan tersebut dengan tingginya responden menyatakan sangat

Berikut digambarkan persentase faktor internal menggunakan diagram lingkaran berdasarkan tabel 1 dapat dilihat pada gambar berikut ini :

Gambar1. Diagram Lingkaran Faktor Internal

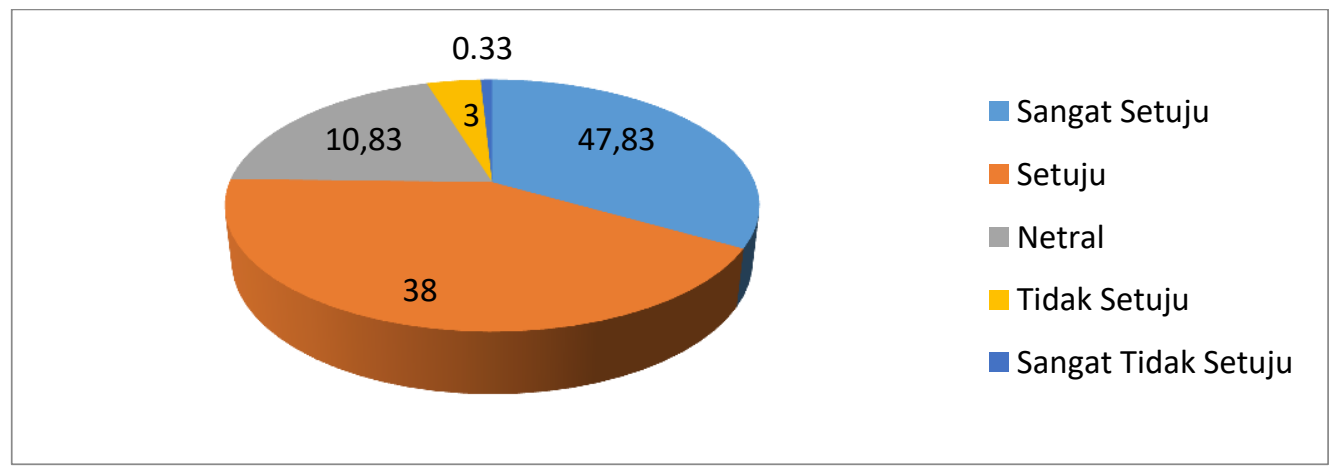

Sumber : Data Olahan (2018)

Berdasarkan diagram lingkaran di atas faktor internal yang menyatakan jawaban sangat setuju lebih banyak dari pada jawaban pernyataan lainnya dengan jumlah persentase sebesar $47,83 \%$.

\section{b. Faktor Eksternal}

Adapun faktor dari luar yang terdiri dari pengaruh lingkungan luar antara lain: intensitas, ukuran, keberlawanan, pengulangan,dan gerakan. 
Tabel 2. Faktor Eksternal

\begin{tabular}{clcccccc}
\hline \multirow{2}{*}{ No } & Butir Pernyatan & \multicolumn{5}{c}{ Skala Pengukuran } & Jumlah \\
\cline { 2 - 6 } & & $\begin{array}{c}\text { Sangat } \\
\text { Setuju }\end{array}$ & Setuju & Netral & $\begin{array}{c}\text { Tidak } \\
\text { Setuju }\end{array}$ & $\begin{array}{c}\text { Sangat } \\
\text { Tidak } \\
\text { Setuju }\end{array}$ \\
\hline 1 & Pernyataan 7 & 22 & 44 & 26 & 8 & 0 & 100 \\
\hline 2 & Pernyataan 8 & 15 & 62 & 18 & 5 & 0 & 100 \\
\hline 3 & Pernyataan 9 & 30 & 47 & 22 & 1 & 0 & 100 \\
\hline 4 & Pernyataan 10 & 22 & 52 & 16 & 8 & 2 & 100 \\
\hline 5 & Pernyataan 11 & 33 & 42 & 24 & 0 & 1 & 100 \\
\hline 6 & Pernyataan 12 & 26 & 34 & 35 & 5 & 0 & 100 \\
\hline 7 & Pernyataan 13 & 33 & 41 & 25 & 1 & 0 & 100 \\
\hline 8 & Pernyataan 14 & 31 & 48 & 20 & 1 & 0 & 100 \\
\hline 9 & Pernyataan 15 & 37 & 32 & 27 & 4 & 0 & 100 \\
\hline 10 & Pernyataan 16 & 38 & 41 & 13 & 7 & 1 & 100 \\
\hline 11 & Pernyataan 17 & 54 & 35 & 5 & 3 & 3 & 100 \\
\hline 12 & Pernyataan 18 & 58 & 28 & 7 & 4 & 3 & 100 \\
\hline & Jumlah & 399 & 506 & 238 & 47 & 10 & 1200 \\
\hline & Persentase & 33,25 & 42,16 & 19,83 & 3,91 & 0,83 & 100 \\
\hline
\end{tabular}

Sumber : Data Olahan (2018)

Berdasarkan tabel 2 dapat dilihat masyarakat, tanggapan tersebut dengan bahwasannya sebagian responden tingginya responden yang menyatakan memiliki faktor eksternal dalam persepsi setuju dengan persentase $42,16 \%$.

Gambar 2. Diagram Lingkaran Faktor Eksternal

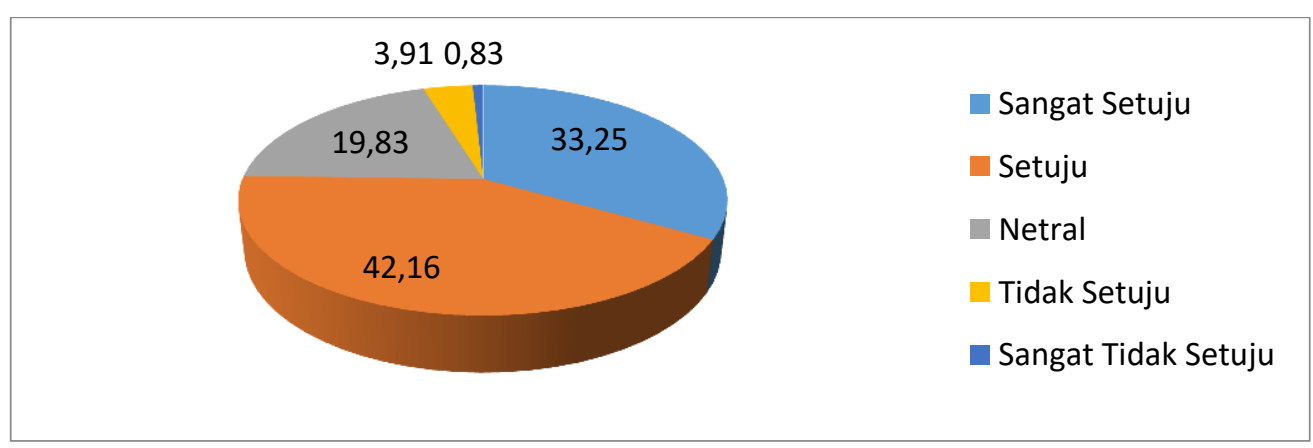

Sumber : Data Olahan (2018)

Berdasarkan diagram lingkaran di atas faktor eksternal yang menyatakan jawaban setuju lebih banyak dari pada jawaban pernyataan lainnya dengan jumlah persentase sebesar $42,16 \%$.

\section{Analisis Data}

Penelitian ini merupakan statistik deskriptif yaitu penyajian data dengan tabel, grafik, diagram lingkaran, dan persentase. Dari data angket yang dikumpulkan dari responden, dibuat data rekapitulasi selanjutnya data ditransformasikan dari data kualitatif 
menjadi data kuantitatif dengan memberikan skor pada angket. Kriteria jawaban dan skor digunakan untuk mentransformasikan data kualitatif berdasarkan jawaban dari para responden pada angket menjadi data kuantitatif dari setiap indikator yang digunakan dalam konsep operasional.

Berikut hasil rekapitulasi dari 18 butir pernyataan melalui angket kepada responden yang telah dipermasalahkan pada penelitian tersebut :

Tabel 3. Rekapitulasi Perhitungan Data Angket

\begin{tabular}{|c|c|c|c|c|c|c|}
\hline \multirow[b]{2}{*}{ Pernyataan } & \multicolumn{5}{|c|}{ Rekapitulasi Perhitungan Data Angket } & \multirow[b]{2}{*}{ Jumlah } \\
\hline & $\begin{array}{l}\text { Sangat } \\
\text { Setuju }\end{array}$ & Setuju & Netral & $\begin{array}{c}\text { Tidak } \\
\text { Setuju }\end{array}$ & $\begin{array}{c}\text { Sangat } \\
\text { Tidak } \\
\text { Setuju }\end{array}$ & \\
\hline Pernyataan 1 & 75 & 20 & 5 & 0 & 0 & 100 \\
\hline Pernyataan 2 & 56 & 31 & 11 & 2 & 0 & 100 \\
\hline Pernyataan 3 & 36 & 48 & 14 & 2 & 0 & 100 \\
\hline Pernyataan 4 & 45 & 40 & 8 & 7 & 0 & 100 \\
\hline Pernyataan 5 & 33 & 45 & 17 & 4 & 1 & 100 \\
\hline Pernyataan 6 & 42 & 44 & 10 & 3 & 1 & 100 \\
\hline $7 \quad$ Pernyataan 7 & 22 & 44 & 26 & 8 & 0 & 100 \\
\hline Pernyataan 8 & 15 & 62 & 18 & 5 & 0 & 100 \\
\hline Pernyataan 9 & 30 & 47 & 22 & 1 & 0 & 100 \\
\hline 10 Pernyataan 10 & 22 & 52 & 16 & 8 & 2 & 100 \\
\hline $11 \quad$ Pernyataan 11 & 33 & 42 & 24 & 0 & 1 & 100 \\
\hline 12 Pernyataan 12 & 26 & 34 & 35 & 5 & 0 & 100 \\
\hline 13 Pernyataan 13 & 33 & 41 & 25 & 1 & 0 & 100 \\
\hline $14 \quad$ Pernyataan 14 & 31 & 48 & 20 & 1 & 0 & 100 \\
\hline 15 Pernyataan 15 & 37 & 32 & 27 & 4 & 0 & 100 \\
\hline 16 Pernyataan 16 & 38 & 41 & 13 & 7 & 1 & 100 \\
\hline $17 \quad$ Pernyataan 17 & 54 & 35 & 5 & 3 & 3 & 100 \\
\hline 18 Pernyataan 18 & 58 & 28 & 7 & 4 & 3 & 100 \\
\hline Jumlah & 686 & 734 & 303 & 65 & 12 & 1800 \\
\hline Nilai Skor & 5 & 4 & 3 & 2 & 1 & \\
\hline Total Skor & 3430 & 2936 & 909 & 130 & 12 & \\
\hline Grand Total Skor & & & & & & 7417 \\
\hline Rata-rata Skor Penelitian & & & & & & 412,05 \\
\hline Persentase & 46.24 & 39.58 & 12.25 & 1.75 & 0,16 & 100 \\
\hline
\end{tabular}

Sumber : Data Olahan Angket (2018)

Berikut digambarkan persentase tentang Persepsi Masyarakat Terhadap perhitungan angket berdasarkan tabel 16 Ekonomi Syariah dan Potensinya 
Terhadap Perkembangan Ekonomi diagram lingkaran dapat dilihat pada Syariah Di Pekanbaru menggunakan gambar berikut ini :

Gambar 3. Diagram Lingkaran Persepsi Masyarakat Terhadap Perkembangan Ekonomi Syariah Di Pekanbaru

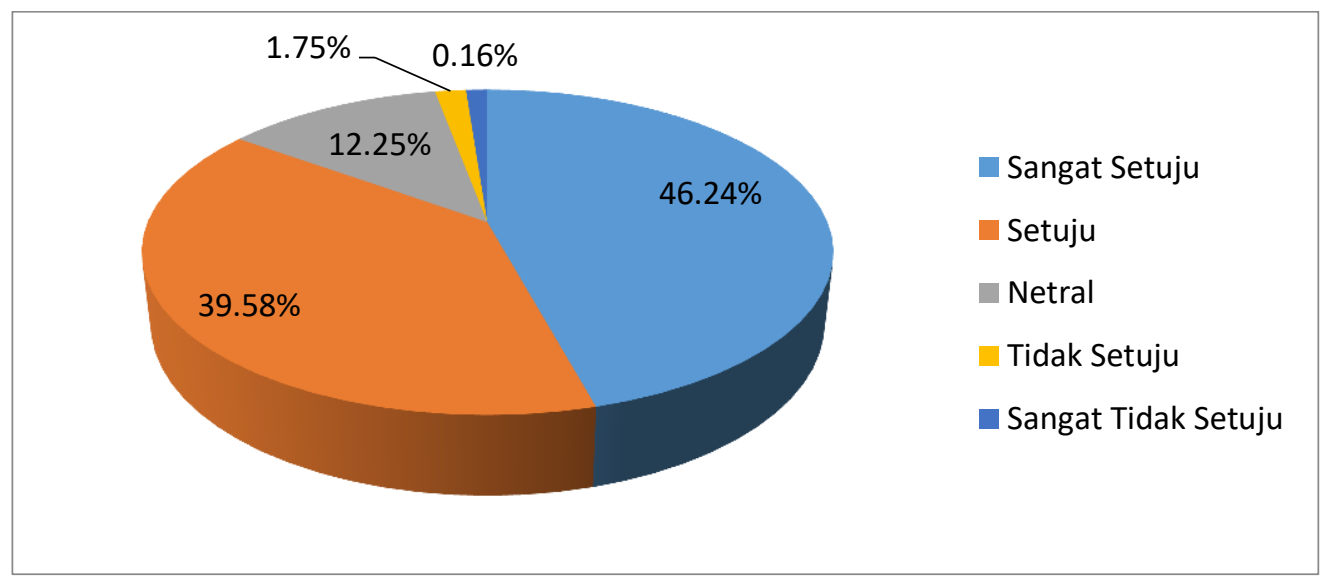

Sumber : Data Olahan (2018)

Berdasarkan data skor yang telah ditetapkan, maka dihitung jawaban dari responden dengan jumlah persentase terbanyak yakni $46.24 \%$ atau $46 \%$ yang selanjutnya akan dibandingkan dengan kriteria analisis deskriptif data dengan persentase $41 \%$ - $60 \%$ yang berarti kriteria jawaban responden terletak pada cukup baik.

Berdasarkan faktor internal yang memiliki 3 indikator yakni : pemahaman, motivasi, kepribadian yang tertera pada angket nomor 1 s/d 6 yang menyatakan sangat setuju sebanyak 47,83\%, yang menyatakan setuju sebanyak $38 \%$, yang menyatakan netral 10,83\%, yang meyatakan tidak setuju sebanyak $3 \%$, dan yang menyatakan sangat tidak setuju sebanyak 0,33\%. Jadi, masyarakat Kota Pekanbaru sangat setuju dengan adanya penerapan sistem ekonomi syariah di Kota Pekanbaru. Karena tingginya responden yang memilih sangat setuju pada faktor internal maka persepsi masyarakat terhadap perkembangan produk perbankan dan IKNB syariah di Kota Pekanbaru cukup baik dengan persentase $47,23 \%$.

Berdasarkan Indikator yang dimiliki oleh faktor eksternal yaitu: intensitas, ukuran, keberlawanan, pengulangan, gerakan, dan kebaruan yang tertera pada angket nomor 7 s/d 18 yang menyatakan sangat setuju sebanyak $33,25 \%$, yang menyatakan setuju sebanyak $42,16 \%$, yang menyatakan netral sebanyak $19,83 \%$, yang menyatakan tidak setuju sebanyak 3,91\%, dan menyatakan sangat tidak setuju sebanyak $0,83 \%$. Jadi, pada faktor eksternal masyarakat Kota Pekanbaru setuju dengan perkembangan produk perbankan dan IKNB Syariah di Kota Pekanbaru.

Dari hasil perhitungan rekapitulasi perhitungan data angket diketahui bahwa persepsi masyarakat terhadap perkembangan produk perbankan dan IKNB Syariah di Kota Pekanbaru adalah "cukup baik" dengan akumulasi jawaban responden sebesar 46,24\%. Seperti gambar dibawah ini : 
Gambar 4. Hasil Skor Kuantinum Persepsi Masyarakat terhadap perkembangan produk perbankan dan IKNB Syariah di Kota Pekanbaru

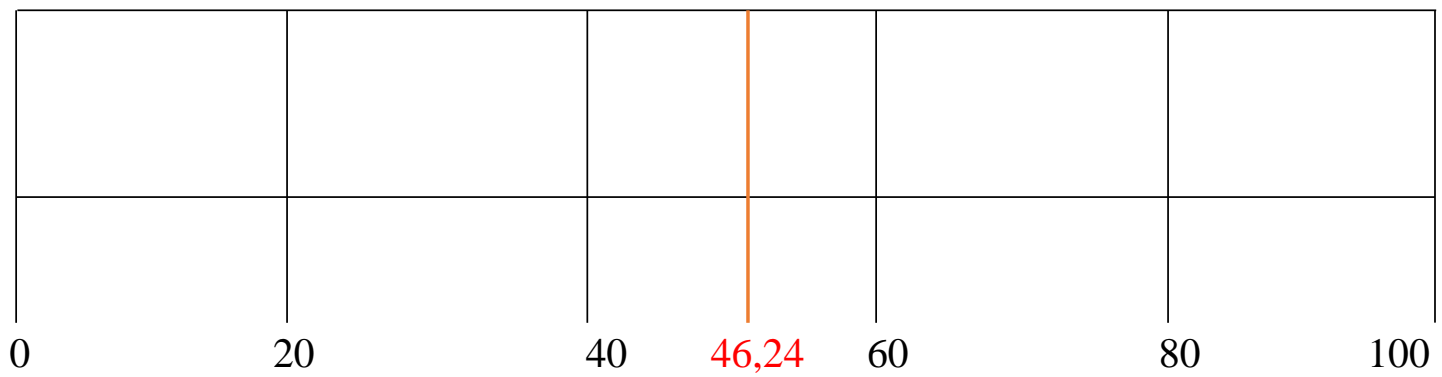

Perkembangan ekonomi syariah IKNB yang berada di Kota Pekanbaru. dapat kita lihat dengan pertumbuhan Berikut adalah tabel perbankan syariah lembaga keuangan perbankan maupun pada tahun 2017 dan 2018:

Tabel 4. Perkembangan Bank Umum Syariah Pada Tahun 2017-2018

\begin{tabular}{cccc}
\hline Tahun & KPO/KC & KCP/UPS & KK \\
\hline 2017 & 11 & 29 & 9 \\
\hline 2018 & 11 & 29 & 8 \\
\hline KPO : Kantor Pusat Operasional & & \\
KC : Kantor Cabang & & &
\end{tabular}

KCP/UPS : Kantor Cabang Pembantu/Unit Pelayanan Syariah

KK : Kantor Kas

Sumber : Statistik perbankan Syariah OJK (2018)

Berdasarkan tabel di atas dapat Kas) bank umum syariah terdapat 9 KK kita lihat bahwasannya telah terjadi sedangkan pada tahun 2018 terjadi penurunan KK (Kantor Kas) pada bank penurunan KK sebesar 1 KK sehingga umum syariah yang berada di Kota pada tahun 2018 hanya terdapat 8 KK Pekanbaru. Pada tahun 2017 KK (Kantor (Kantor Kas) bank umum syariah.

Gambar 5. Perkembangan Bank Umum Syariah Pada Tahun 2017-2018

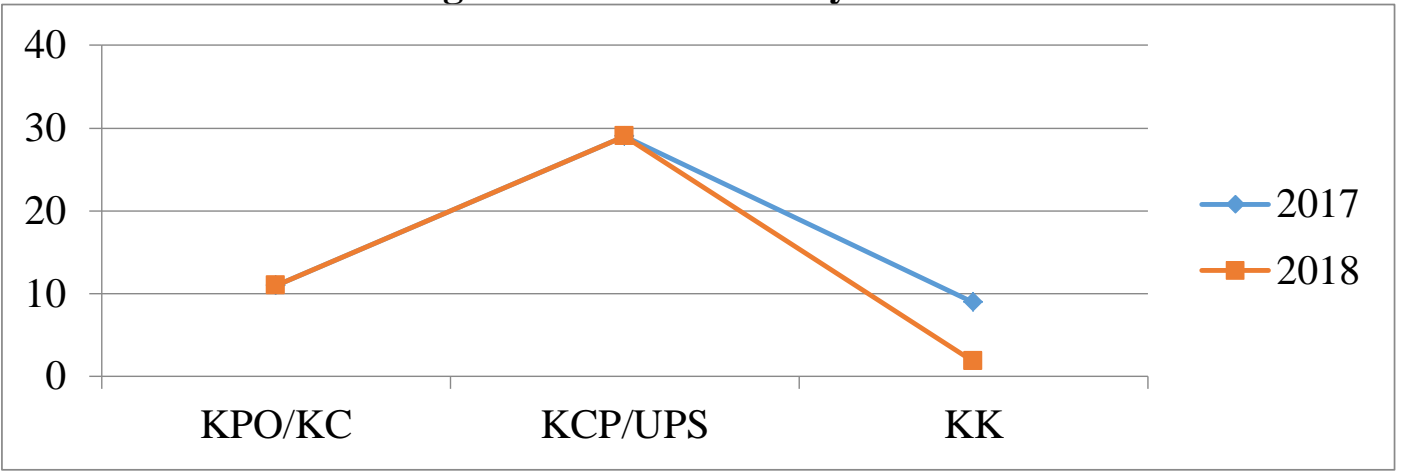

Sumber : Data Olahan (2018)

Dari gambar di atas dapat kita lihat bahwasannya perkembangan bank umum syariah pada tahun 2017-2018 terjadi pengurangan pada KK yakni sebanyak 1
KK. Sehingga pada tahun 2018 hanya terdapat 8 KK sedangkan pada tahun 2017 terdapat $9 \mathrm{KK}$. 
2022, Jurnal Tabarru' : Islamic Banking and Finance 5 (1) : 12 - 23

Tabel 5. Perkembangan Unit Usaha Syariah Pada Tahun 2017-2018

\begin{tabular}{cccc}
\hline Tahun & KPO/KC & KCP/UPS & KK \\
\hline 2017 & 3 & 3 & 3 \\
\hline 2018 & 3 & 3 & 4 \\
\hline KPO : Kantor Pusat Operasional & & \\
KC : Kantor Cabang & &
\end{tabular}

KCP/UPS : Kantor Cabang Pembantu/Unit Pelayanan Syariah

KK : Kantor Kas

Sumber : Statistik perbankan Syariah OJK (2018)

Berdasarkan tabel di atas terjadi

tahun 2017 hanya ada $3 \mathrm{KK}$, sedangkan peningkatan pada KK unit usaha syariah pada tahun 2018 terjadi penambahan 1 pada tahun 2018 sebesar 1 KK. Pada KK menjadi 4 KK unit usaha syariah.

Gambar 6. Perkembangan Unit Usaha Syariah Pada Tahun 2017-2018

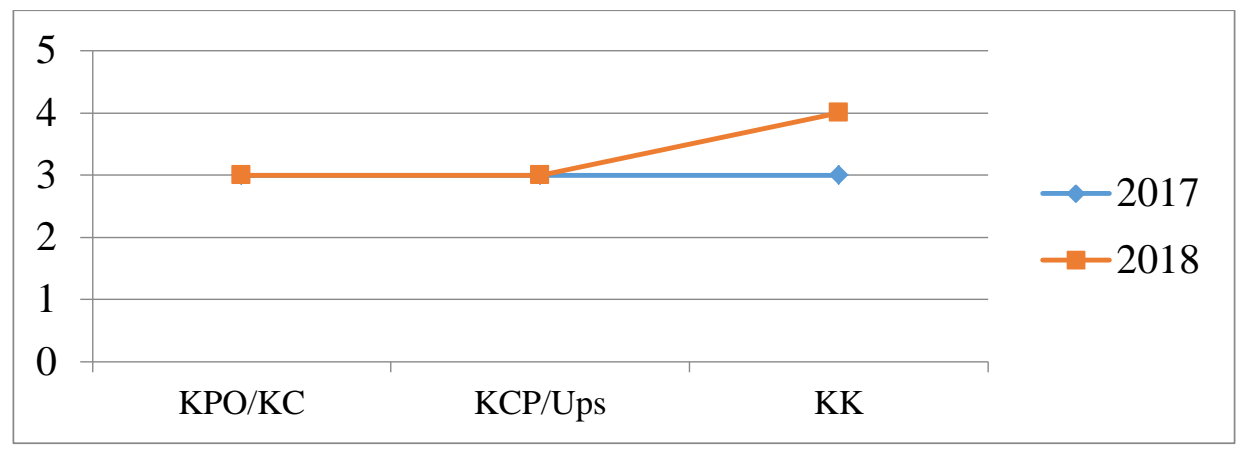

Sumber : Data Olahan (2018)

Dari gambar di atas dapat kita lihat bahwasannya unit usaha syariah pada tahun 2017-2018 terdapat peningkatan pada KK yakni bertambahnya 1 KK pada tahun 2018.

\section{KESIMPULAN}

Berdasarkan hasil pembahasan tentang persepsi masyarakat terhadap perkembangan produk perbankan dan IKNB syariah di Kota Pekanbaru yang telah diolah melalui jawaban responden yang populasinya 1.091 .088 orang dengan sampel 100 orang dari 12 Kecamatan yang ada di Kota Pekanbaru. Maka, dapat disimpulkan bahwa persepsi masyarakat Kota Pekanbaru berada pada skor 46,24\%, yang berarti persepsi masyarakat terhadap perkembangan ekonomi syariah dan potensinya terhadap perkembangan produk perbankan dan IKNB syariah di
Kota Pekanbaru adalah "cukup baik". Maknanya persepsi masyarakat terhadap perkembangan produk perbankan dan IKNB syariah di Kota Pekanbaru.

\section{DAFTAR PUSTAKA}

Boeree, George. 2016. General Psychology. Prismasphie. Jogjakarta.

Ismawati, Esti. 2012. Ilmu Sosial Budaya Dasar. Ombak. Yogyakarta.

Karim, Adiwarman. 2014. Bank Islam Analisis Fiqih Dan Keuangan. PT. Raja Grafindo Persada. Jakarta.

Muhammad. 2008. Metodologi Penelitian Ekonomi Islam. Raja Wali Pres. Jakarta.

Mursidin. 2010. Psikologi Umum. CV. Pustaka Setia. Bandung. 
Pusat Kajian dan Pengembangan Ekonomi Islam (P3EI) UIIY. 2015, Ekonomi Islam. Rajawali Pers. Jakarta.

Rakhmat, Jalaluddin. 2012. Psikologi Komunikasi. PT. Remaja Rosdakarya. Bandung.

Ridwuan. 2014. Dasar-Dasar Statistika, Alfabeta. Bandung.

Rozalinda. 2014. Ekonomi Islam. PT. Rajagrafindo Parsada. Jakarta.

Sanusi, Anwar. 2016. Metodologi Penelitian Bisnis. Salemba Empat. Jakarta.

Soemitra, Andri. 2009. Bank dan Lembaga Keuangan Syariah. Kencana. Jakarta.

Toha, Miftah. 2008. Perilaku Organisasi Konsep Dasar Dan Aplikasinya. PT. Rajagrafindo Persada. Jakarta.

Usman, Rachmadi. 2012. Aspek Hukum Perbankan Syariah Di Indonesia. Sinar Grafika. Jakarta.

Winardi. 2015, Manajemen perilaku Organisasi. Prenadamedia Group. Jakarta. 